\title{
Konsep Ekonomi Mercantilisme
}

\author{
Rezki Amalia Fathurrahman (90100118108) \\ Email:rezkiamalia56@gmail.com
}

\begin{abstract}
Abstrak
Seperti bahwa merkantilisme adalah suatu teori ekonomi yang mengatakan bahwa sejahtera di suatu negara ditentukan oleh berapa asset modal atau harta yang dimiliki dan besar volume perdagangan luar negeri. Konsep merkantalisme ini di sudah di jelaskan oleh beberapa tokoh pemikirnya seperti Jean Bodin seorang Filsuf dari Perancis yang membahas teori tentang uang dan harga yang menurut pendapatnya bahwa bertambah uang dan pendapatan di peroleh dari perdagangan luar negeri yang menyebabkan harga barang dari luar negeri ini menjadi naik karena bea impor dan juga pajak yang harus di keluarkan. Thomas Mun seorang saudagar dari Inggris yang membahas teori surplus perdagangan yang menurutnya bahwa surplus perdagangan atau pendapatan lebih bisa memakmurkan negara secara ekonomi. Jean Baptiste Colbert seorang pejabat negara menteri ekonomi dan keuangan dari Perancis yang membahas tentang bahwa kedudukan saudagar sangat penting dan saudagar dan penguasa atau pemerintah bersatu dalam memajukan suatu perekonomian di negaranya. Sir Willian Petty seorang ekonom, ilmuwan sekaligus filsif dari Inggris yang membahas tentang teori ekonomi dan aritmatika politik, teori tenaga kerja dan teori uang. David Hume yang lahir di Skotlandia yang membahas tentang teori harga yang mengatakan bahwa harga di pengaruhi oleh jumlah barang dan jumlah uang.
\end{abstract}

Kata Kunci: Merkantilisme, Surplus Perdagangan, Uang dan Harga, Perdagangan Luar Negeri. 


\section{Pendahuluan}

Sebelum membahas tentang tokoh pemikir ekonomi tentang merkantilisme kita harus dulu mengetahui apa itu merkantalisme. Merkantalisme adalah teori bahwa kesejahteraan disuatu negara di tentukan oleh banyak asset yang dimiliki negara atau modal yang disimpan oleh negara dan besarnya volume perdagangan luar negeri juga sangat penting. Menurut paham merkantilisme ini bahwa setiap negara menginginkan suatu kemajuan salah satunya melakukan perdagangan luar negeri yang bisa menambah suatu pendapatan dan Uang yang dihasilkan menjadi Surplus Perdagangan yang menjadi kunci sumber kekuasan maksudnya negara akan maju jika memiliki uang yang banyak lalu di simpan dan nanti uang itu digunakan untuk memproduksi barang lalu di ekspor keluar.(Ubaid Al Faruq dan Edi Mulyanto 2017)

Selain itu juga ada beberapa tokoh pemikiran yang membahas tentang merkantilisme seperti Jean Bodin (1530-1596) ilmuwan dari Perancis yang membahas tentang teori uang dan harga secara sistematis atau rinci. Thomas Mun (1571-1641) saudagar kaya dari Inggris yang membahas tentang pengalaman perdagangan luar negeri dan permasalahan yang sering terjadi dalam perdagangan luar negeri. Jean Baptiste Colbert (1691-1683) seorang pejabat dari Perancis yang menjabat sebagai menteri ekonomi dan keuangan yang membahas tentang kebijakannya lebih kearah kekuasaan dan kejayaan negara yang bekerja sama dengan pengusaha untuk meningkatkan kekayaan secara individu. Sir William Petty (1623-1687) seorang ekonomi, ilmuwan sekaligus filsuf dari Inggris yang 
membahas tentang bahwa penting tenaga kerja (Labor) daripada sumber daya tanah untuk meningkatkan perekonomian dalam negeri. David Hume (1711-1776) yang lahir dari Skotlandia yang merupakan sahabatnya Adam Smith yang bukunya berjudul of Balance of Trade yang membahas tentang harga-harga yang sebagian di pengaruhi oleh jumlah uang dan barang yang beredar.(Aljanbar 2017) 


\section{Pembahasan}

Tokoh pemikir ekonomi tentang merkantilisme yang pertama yaitu Jean Bodin(1530-1596) yang lahir di Angres Perancis yang dimana teorinya membahas tentang teori uang dan harga secara sistematis yang menurutnya bahwa bertambah uangnya disebabkan terjadinya perdagangan luar negeri yang menyebabkan harga barang menjadi naik. Penyebab naiknya barang disebabkan oleh praktik monopoli dan pola hidup yang dilakukan yang para bangsawan dan raja-raja pada masa itu. Salah faktor yang menyebabkan harga barang-barang menjadi naik menurut Bodin ada 5 yaitu:

1. Bertambah logam mulia seperti perak dan emas.

2. Praktek monopoli atau penguasan harta kekayaan baik dilakukan pihak swasta maupun negara atau pemerintah.

3. Jumlah barang di dalam negeri menjadi langka karena sebagian barang di ekspor keluar negeri.

4. Pola hidup mewah oleh kalangan kaum bangsawan dan raja-raja.

5. Menurun nilai mata uang logam karena menurutnya isi karat yang terkandung harus dikurangi atau dipermainkan.(Ubaid Al Faruq dan Edi Mulyanto 2017)

Tokoh yang kedua yaitu Thomas Mun (1571-1641) seorang saudagar dari Inggris yang dalam bukunya berjudul "England Treasure by Foreign Trade" yang menulis tentang manfaat perdagangan luar negeri. Karena menurut buku yang ia tulis bahwa dengan perdagangan luar negeri akan memperkaya suatu negara, jika negara menghasilakn surplus perdagangan dalam bentuk emas dan perak.(Siti 
Mujiatun 2014). Selain itu juga adapun langkah-langkah untuk meningkatkan surplus perdagangan sebagai berikut. (Ubaid Al Faruq dan Edi Mulyanto 2017)

1. Kebijakan Harga, jika mengekpor harus dengan harga yang terbaik yiatu harga yang menghasilkan pendapatan dan kekayaan yang banyak. Maka dari itu harga barang yang diekspor harus tinggi kecuali ketika ada persaingan perdagangan dengan negara lain maka harga barang yang diekspor harus diturunkan harganya agar bisa bersaing dengan pedagang lain.

2. Kualitas barang, maksudnya barang yang dijual harus bagus dan berkualitas maka dari itu pemerintah Inggris membentuk dewan perdagangan dan membuat peraturan-peraturan untuk mengatur para pengusaha agar menghasilkan barang yang berkualitas tinggi.

3. Kebijakan Pajak Nasional, dengan bea Ekspor harus lebih rendah daripada bea impor agar barang yang diekspor keluar negeri nantinya akan menghasilkan pendapatan negara yang cukup tinggi jika bea Ekspor dan pajak di kurangi.

Tokoh pemikir merkantilisme ketiga yaitu, Jean Baptiste Colbert (16191683) yang lahir Reims Perancis merupakan pejabat yang menjabat sebagai Menteri Ekonomi dan Keuangan yang membuat kebijakan untuk melakukan penghematan anggaran kerajaan tanpa henti itu disebabkan oleh terjadi perang sehingga membutuhkan biaya lebih untuk perang. Selain itu juga karena pada masa itu perdagangan luar negeri sebagai sumber kemakmuran maka terjadi aliansi antara saudagar dengan penguasa. Dimana penguasa memberi bantuan dan perlindungan terhadap saudagar berupa monopoli (penguasaan barang), proteksi, dan 
memberikan keistimeawaan kepada saudagar sehingga di Eropa dianggap sebagai zaman kapitalisme saudagar (Merchant Capitlism). Tujuan penguasaan ini adalah untuk tetap menjaga kekuasaan negara dan meningkatkan kekayaan secara individu. Selanjutnya tokoh pemikir merkantilisme keempat yaitu, Sir Willian Petty (1623-1687) seorang ekonom, ilmuwan dan filsuf dari Inggris yang merupakan anggota parlemen Inggris dan anggota Piagam Royal Society untuk teori yang berjudul ekonomi dan metode aritmatika politik dikaitkan dengan filosofi "Laissez Faire" yang berkaitan dengan pemerintah. Selain itu juga ia membahas tentang kebijakan Fiskal yang dimana menurut pendapat bahwa negara yang bijak adalah negara yang tidak menggunakan uang atau pendapatan negara untuk dihabiskan dan tidak setuju adanya defisit anggaran atau kekurangan anggaran. Selain itu Petty mendukung pajak konsumsi yang dimana dalam penggambilan pajak harus horizontal atau adil, teratur dan proporsional. Selain itu Petty mendukung tenaga kerja (Labour) adalah hal yang penting di banding sumber daya tanag (Land) karena menurutnya bukan jumlah hari kerja yang ditentukan tetapi kinerja para pekerja dan biaya upah yang ditentukan agar para buruh bisa berkerja dengan lebih baik lagi. Tokoh pemikir merkantilisme yang terakhir yaitu David Hume (1711-1776) yang lahir di Skotlandia yang bersahabat dengan Adam Smith yang terkenal dengan bukunya berjudul "of The Balance of Trade" yang membicarakan tentang hargaharga yang sebagian di pengaruhi oleh jumlah barang dan jumlah uang yang beredar. Selain itu Hume membahas tentang faktor keadilan dan beranggapan jika tidak berlaku adil maka memperlemah suatu negara karena menurutnya setiap warga negara berhak untuk menikmati hasil kerja keras dan diberi kesempatan 
untuk mengelola. Jika tidak bisa berlaku adil maka kaum orang kaya ini harus mendistribusikan kekayaan kepada kaum miskin yang membutuhkan.(Ubaid Al Faruq dan Edi Mulyanto 2017)

Jadi konsep David Hume sesuai dengan konsep ekonomi Islam tentang konsep harga yang dimana menurut Ekonomi Islam bahwa harga yang adil adalah harga yang mampu bersaing sempurna secara pasar antara penjual dan pembeli menurut mekanisme pasar. Jika mekanisme pasar terganggu maka harga yang adil tidak tercapai selain itu juga dalam ekonomi Islam harta yang berlebih harus dibagikan kepada yang mebutuhkan.(Idris Parakassi dan Kamiruddin 2018) 


\section{Kesimpulan}

Bahwa Merkantilisme adalah teori bahwa kesejahteraan disuatu negara di tentukan oleh banyak asset yang dimiliki negara atau modal yang disimpan oleh negara dan besarnya volume perdagangan luar negeri juga sangat penting. Yang konsep ini melahirkan tokoh pemikir ekonomi tentang merkantilisme seperti Jean Bodin yang membahas tentang teori uang dan harga secara sistematis yang menurut pendapatnya bahwa bertambah uangnya disebabkan terjadinya perdagangan luar negeri yang menyebabkan harga barang menjadi naik. Thomas Mun yang membahas tentang dalam bukunya berjudul "England Treasure by Foreign Trade" yang menulis tentang manfaat perdagangan luar negeri. Karena menurut buku yang ia tulis bahwa dengan perdagangan luar negeri akan memperkaya suatu negara, jika negara menghasilakn surplus perdagangan dalam bentuk emas dan perak. Jean Baptiste Colbert yang membahas tentang kebijakan untuk melakukan penghematan anggaran kerajaan tanpa henti itu disebabkan oleh terjadi perang sehingga membutuhkan biaya lebih untuk perang. Selain itu juga karena pada masa itu perdagangan luar negeri sebagai sumber kemakmuran maka terjadi aliansi antara saudagar dengan penguasa. Dimana penguasa memberi bantuan dan perlindungan terhadap saudagar berupa monopoli (penguasaan barang), proteksi, dan memberikan keistimeawaan kepada saudagar. Sir Willian Petty yang membahas tentang kebijakan Fiskal yang dimana menurut pendapat bahwa negara yang bijak adalah negara yang tidak menggunakan uang atau pendapatan negara untuk dihabiskan dan tidak setuju adanya defisit anggaran atau kekurangan anggaran. Selain itu Petty mendukung pajak konsumsi yang dimana dalam penggambilan 
pajak harus horizontal atau adil, teratur dan proporsional. David Hume yang membahas tentang bukunya berjudul "of The Balance of Trade" yang membicarakan tentang harga-harga yang sebagian di pengaruhi oleh jumlah barang dan jumlah uang yang beredar. 


\section{Daftar Pustaka}

Aljanbar, Fakthur Rahman. 2017. "Pemikiran Ilmu Ekonomi (Analisis Komparatif Ekonomi Masa Pra Klasik Dan Masa Rasulullah SAW).” Eksyar 1(1):20-36.

Idris Parakassi dan Kamiruddin. 2018. "Analisis Harga Dan Mekanisme Pasar Dalam Perspektif Islam.” Laa Maisyir 5(1):107-20.

Siti Mujiatun. 2014. "Peran Pemerintah Tentang Pengembangan Perekonomian Dalam Perspektif Sistem Ekonomi Kapitalis, Sosialis, Dan Islam.” Jurnal Analytica Islamica 3(1):90-107.

Ubaid Al Faruq dan Edi Mulyanto. 2017. Sejarah Teori-Teori Ekonomi. Tangerang Selatan: UNPAM PRESS. 